$\mathbb{T}$ periodica polytechnica

Civil Engineering

$55 / 1(2011) 3944$

doi: 10.3311/pp.ci.2011-1.05

web: http://www.pp.bme.hu/ci

(c) Periodica Polytechnica 2011

RESEARCH ARTICLE

\section{Some geotechnical aspects of bioreactor landfills}

\author{
Gabriella Varga
}

Received 2010-04-16, revised 2010-06-10, accepted 2010-06-24

\begin{abstract}
In waste management, recent global practices are shifting the attention toward utilization of landfill gas generation and the deployment of bioreactors. This puts emphasis on the internal processes of bioreactor landfill and the analysis of slope stability of such landfills. We examined bioreactor landfills stability with respect to degradation. Our model divided the waste body into five layers according to the degree of decomposition. Three different geometries were simulated. We used PLAXIS and GEOSLOPE program in our simulations then we compared their results.
\end{abstract}

\section{Keywords}

bioreactor landfill · degradation · factor of safety · slope stability $\cdot$ Plaxis $\cdot$ Geoslope

\section{Acknowledgement}

The support of the National Research Fund Jedlik Ányos NKFP B1 200608 and the Norwegian research fund HU-0121 was used for this research. This work is connected to the scientific program of the "Development of quality-oriented and harmonized $R+D+I$ strategy and functional model at BME" project. This project is supported by the New Hungary Development Plan (Project ID: TÁMOP-4.2.1/B-09/1/KMR-2010-0002).

\section{Gabriella Varga}

Department of Geotechnics, BME, H-1111 Budapest Múegyetem rkp. 3., Hungary

e-mail: varga_gabriella@hotmail.com

\section{Introduction}

There are many geotechnical aspects to landfill designs. It is of high importance to select an optimal location based on environmental, geotechnical, and geophysical examinations [16]. Lining system design, examination of MSW slope stability, coordination of gas generation, monitoring system design, leachate management, and waste settlement analysis are all in the center of landfill design. Nevertheless, recent global practices are shifting the attention toward utilization of landfill gas generation and the deployment of bioreactors [11]. This puts emphasis on the internal processes of bioreactor landfill and the analysis of slope stability of such landfills [8].

In order to analyze long term behaviour of landfills it is a common practice to compare the results of field evaluations and laboratory tests with the results of computer-based modeling. Comparing the models applied in recent studies brings up numerous issues [1, 13]. Studying landfill behaviour in a laboratory setting is a difficult task because the material to be analyzed is heterogeneous, and the largest diameter of particles is, depending on the landfill management technique, may go as high as 0.1 meter to 1 meter. Therefore, the number of places where such laboratory tests can be performed are very limited.

Rapid growth of population, urbanization, economic growth, and the increase in the standard of living have all contributed to the fast increase of municipal solid waste. More waste coupled with increasing prices of sites forced engineers to design higher and steeper landfills for better utilization. Changes in the size of landfills result in increased sheer strength. In the analysis of long term behaviour of landfills, slope stability analysis plays a major role because the gas and leachate pipes, the monitoring and lining system can easily get damaged [3, 12].

There have been numerous significant creeps and slope failures in the waste body, which had caused serious damage to the gas and leachate system making them unusable. Therefore, to minimize such risk the sheer strength of stabilized waste needs to better defined in order to provide appropriate input for examination of bioreactor landfill stability [2].

In the past two decades numbers of catastrophic slope failures have occurred in controlled and uncontrolled landfills causing 
environmental and economic damages while killing thousands of people [9, 14].

\section{Bioreactor Process Overview and the Phasis of Waste Decomposition}

Acceleration of the degradation of MSW is the primary function of the bioreactor landfill. This is achieved by enhanced biomechanical processes that transform and stabilize the decomposable organic waste. This reduces the standard 30- to 100-year degradation time of conventional landfills to 5 to 10 years. In bioreactor landfills the time needed for total consolidation decreases while the amount and the quality of biogas increases. With the accelerated degradation and consolidation the amount of waste that can be deposited is growing which has significant financial impact. The above advantages shift waste management to bioreactor landfill operation all over the world. A bioreactor landfill can be classified as anaerobic, aerobic or hybrid [7, 10]. In order to achieve optimal moisture levels moisture is added to waste in anaerobic bioreactor landfills. A municipal solid waste landfill can be treated as a huge anaerobic bioreactor with degradable organic patterns.

Pohland et. al. describe five distinct phases of waste decomposition [6, 11]:

- Phase I (lag phase). It is an acclimation period in which moisture starts accumulating and aerobic bacteria begins to consume the oxygen trapped in freshly deposited solid waste.

- Phase II (transition phase). This is the first anaerobic phase where total volatile acid (TVA) reaches a detectable level and chemical oxygen demand (COD) increases.

- Phase III (acid formation phase). The second anaerobic phase is characterized by microbial conversion of biodegradable organic content and the activity of acidogenic bacteria increases.

- Phase IV (Methane fermentation phase). In this phase intermediate acids are consumed by methanogenic bacteria and converted into methane and carbon dioxide.

- Phase V (Maturation phase). A marked drop in landfill gas production, stable concentrations of leachate constituents, and the continued relatively slow degradation of recalcitrant organic matter characterize this phase.

In our computer based simulation we divided the waste body into five layers, corresponding to the degree of decomposition. We varied the parameters of waste layers according to the degradation phases.

\section{Slope Stability Analysis}

In our simulations the degree of decomposition was taken into account when performing the stability analysis of a bioreactor landfill. We performed our calculations with the help of the PLAXIS finite element modul and the GEOSLOPE program then we compared the results they produced. Different landfilling techniques were simulated by different geometries.

\subsection{Static Slope Stability Analysis with PIAXIS 8.0}

The stability of bioreactor landfill as a function of decomposition was analyzed.

\subsubsection{Finite element modeling}

Figure 1 depicts the cross-section of the landfill under examination. Five layers corresponding to the five degradation phases were defined. Characteristics of each layer change with degradation, thus their parameters continuously need to be adjusted. The bioreactor landfill is modeled as a two dimensional plane strain model with a $3 \mathrm{H}: 1 \mathrm{~V}$ slope.

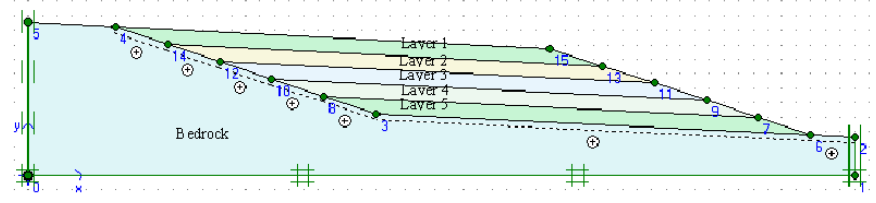

Fig. 1. Cross-section of the examined landfill

\subsubsection{Mesh Generation and Boundary Conditions}

In our modeling we used 15-nodded triangle elements. The cross-section of the generated mesh is shown in Fig. 2. The foundation soil was considered to be stiff soil, thus its stability was not analyzed.

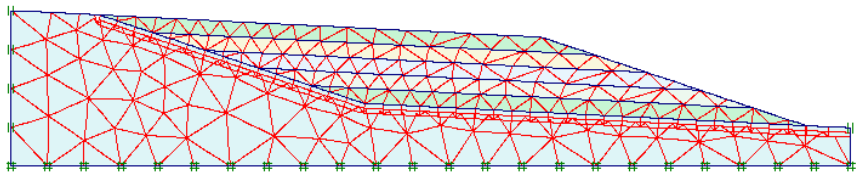

Fig. 2. Cross-section of the generated mesh

\subsubsection{Material Model and Type of Analysis}

The analysis used the Mohr- Coulomb model. This model involves five parameters, namely Young's modulus, E, Poisson's ratio, $v$, the cohesion, $c$, the friction angle, $\varphi$, and the dilatancy angle, $\psi[15]$. The dilatancy angle was assumed to be zero. Table 1 summarizes the parameters used in the FEM analysis of different phases of decomposition. Since Hungarian laboratories are limited in tools to perform waste examinations we used data collected from the literature [5].

Unit weight of solid waste has a major effect on estimating the stability of landfills. The type of waste, the degree of decomposition and compaction, and the depth from which the sample is taken all influence unit weight [17]. The higher the degree of decomposition, the larger the unit weight is. With degradation, larger particles in MSW break into smaller pieces, which reduce the voids and increase the density of solid waste. In Plaxis one 
Tab. 1. Parameters for M-C Model in FEM analysis

\begin{tabular}{lccccc}
\hline & $\begin{array}{c}\text { Unit Weight } \\
\gamma\left(\mathrm{kN} / \mathrm{m}^{3}\right)\end{array}$ & $\begin{array}{c}\text { Permeability } \\
k\left(\mathrm{~m} / \text { day } \times 10^{-3}\right)\end{array}$ & $\begin{array}{c}\text { Poisson's } \\
\text { ratio }\end{array}$ & $\begin{array}{c}\text { Cohesion } \\
c(\mathrm{kPa})\end{array}$ & $\begin{array}{c}\text { Friction angle } \\
\varphi\left({ }^{\circ}\right)\end{array}$ \\
\hline Phase 1. & 9,01 & 190 & 0,25 & 11,2 & 26,7 \\
\hline Phase 2. & 9,44 & 173 & 0,4 & 20,5 & 21,5 \\
\hline Phase 3. & 9,80 & 151 & 0,41 & 12,9 & 21,0 \\
\hline Phase 4. & 10,22 & 130 & 0,42 & 5,3 & 20,6 \\
\hline Phase 5. & 11,02 & 86 & 0,45 & 2,4 & 19,0 \\
\hline
\end{tabular}

may use multiple stiffness moduli, such as shear modulus, $G$, and the odometer modulus, $E_{\text {oed }}$. According to Hooke's law of isotropic elasticity, which involves Poisson's ratio, these moduli are related to Young's modulus. Poisson's ratio is higher for waste with advanced stage of decomposition than for freshly deposited waste. The factor of safety was determined using the $\varphi$-c reduction method of Plaxis. It was computed for each stage respectively. This is in line with the EUROCODE stability analysis.

\subsubsection{Cases Analyzed}

Particles in a closed landfill may be characterized by a composition of cells of different age and different waste stage. Based on the age of waste five groups are defined: aerobic phase, first anaerobic phase, second anaerobic phase, accelerated methane production phase, and decelerated methane production phase. The layers in our analysis are representing the phases of waste decomposition. Right after the closure of the landfill, Layer 1 is in the initial phase of decomposition while the other layers are assumed to be in Phase II through V. As decomposition progresses layers moves to the next phase of decomposition. Table 2 shows the phase of decomposition for each layer as a function of time. Based on that, stability analysis of the landfill was divided to five stages.

Tab. 2. Phases of decomposition at different stages

\begin{tabular}{llllll}
\hline & Layer 1 & Layer 2 & Layer 3 & Layer 4 & Layer 5 \\
\hline Stage 1 & Phase 1 & Phase 2 & Phase 3 & Phase 4 & Phase 5 \\
\hline Stage 2 & Phase 2 & Phase 3 & Phase 4 & Phase 5 & Phase 5 \\
\hline Stage 3 & Phase 3 & Phase 4 & Phase 5 & Phase 5 & Phase 5 \\
\hline Stage 4 & Phase 4 & Phase 5 & Phase 5 & Phase 5 & Phase 5 \\
\hline Stage 5 & Phase 5 & Phase 5 & Phase 5 & Phase 5 & Phase 5 \\
\hline
\end{tabular}

\subsubsection{Effect of Decomposition on MSW Stability}

Decomposition was found to have a significant impact on stability. The factor of safety decreased with advanced decomposition. As we mentioned above, with time, every layer of waste advanced to the next phase of decomposition, which degraded their stability properties. In stage 5 the waste body collapsed and the factor of safety dropped below 1, which explains the lack of a total displacement curve in that phase.

Fig. 3 depicts the evaluation of failure surfaces at different stages of decomposition. With time, failure surfaces have moved up along the slope risking the stability of a larger and larger waste body. As the decomposition of MSW in bioreactor landfills advances the extent of the collapsed waste body increases, which can result in a catastrophic failure and may compromise the utilization of the landfill.

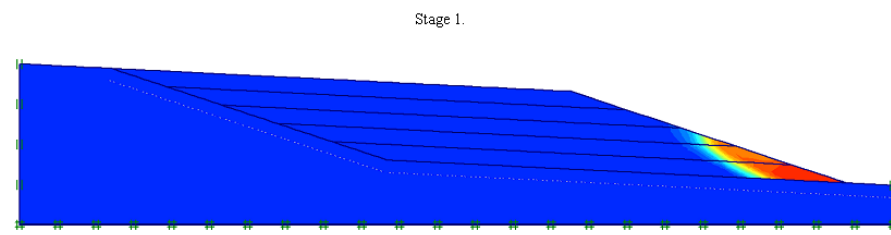

Stage 2

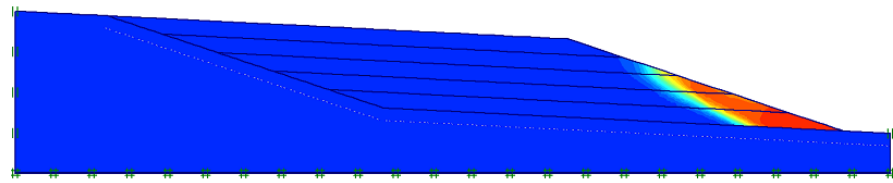

Stage 3

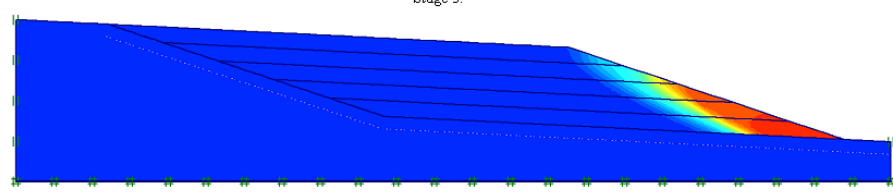

Stage 4

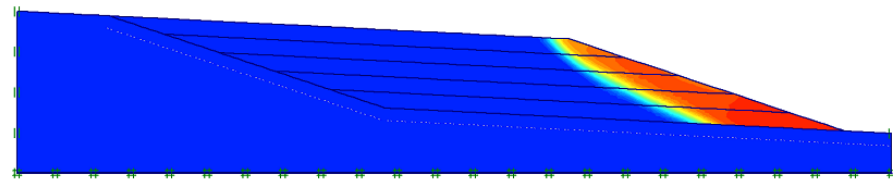

Fig. 3. Total incremental displacements from PLAXIS 8.0 at different stages of decomposition

Factors of safety from PLAXIS at different stages of decomposition are shown in Table 3 .

Decrease in sheer strength results in a decreased safety factor. Based on these result we suggest taking time and the phase of decomposition into account when analyzing the stability of landfills rather than using average values or values determined 
Tab. 3. Factors of safety from PLAXIS and GEOSLOPE at different stages of decomposition

\begin{tabular}{cccccc}
\hline & Stage 1 & Stage 2 & Stage 3 & Stage 4 & Stage 5 \\
\hline PLAXIS & 1,155 & 1,077 & 1,037 & 1,015 & - \\
\hline
\end{tabular}

at deposition.

When reviewing the stability of landfills it is recommended to use degradation dependent soil mechanical parameters. Resulting factors of safety are smaller than factors of safety coming from freshly deposited waste parameters. In order to achieve safe operation degree of decomposition is not to be neglected.

\subsection{Static Slope Stability Analysis with GEOSLOPE Pro- gram}

The examined bioreactor landfill stability problems have also been solved with the help of the Geoslope computer simulation. We used the same solid waste parameters, dimensions, and procedure as those of the FEM analysis. The aim of the calculations is to determine the critical failure surface that belongs to the lowest factor of safety. Our calculations were based on the Morgenstern-Price method [4].

\subsubsection{Effect of Decomposition on MSW Stability using GEOSLOPE simulation}

Critical failure surfaces and factors of safety from GEOSLOPE at different stages of decomposition are shown in Fig. 4.

Similarly to the results of FEM analysis factors of safety decreased with the advancement of degradation, while critical failure surface extended. Table 4 shows factors of safety from PLAXIS and GEOSLOPE simulations at the 5 stages of decomposition analyzed. The results of the two simulations are very close, with GEOSLOPE having slightly lower values that can be explained with the differences in their respective models.

Tab. 4. Factors of safety at different stages of decompositions in case of parallel and staggered built landfills using PLAXIS and GEOSLOPE simulations

\begin{tabular}{cccccc}
\hline & Stage 1 & Stage 2 & Stage 3 & Stage 4 & Stage 5 \\
\hline PLAXIS & 1,155 & 1,077 & 1,037 & 1,015 & - \\
\hline GEOSLOPE & 1,148 & 1,052 & 1,015 & 0,993 & 0,962 \\
\hline
\end{tabular}

\subsection{Effect of Landfill Geometry on Safety Factor}

In Hungary numerous landfilling techniques are applied. Time needed to fill up a large landfill may take 1-2 decades where wastes of different age are in different phases of degradation. In order to examine the effect of different landfill geometries on the factor of safety we performed calculations with both aslope and staggered built landfills. In case of aslope built landfill (Fig. 5), we have found a failure already in the first layer when simulating deposition. However, when simulating a settled waste body the factor of safety was higher than 1 . We can
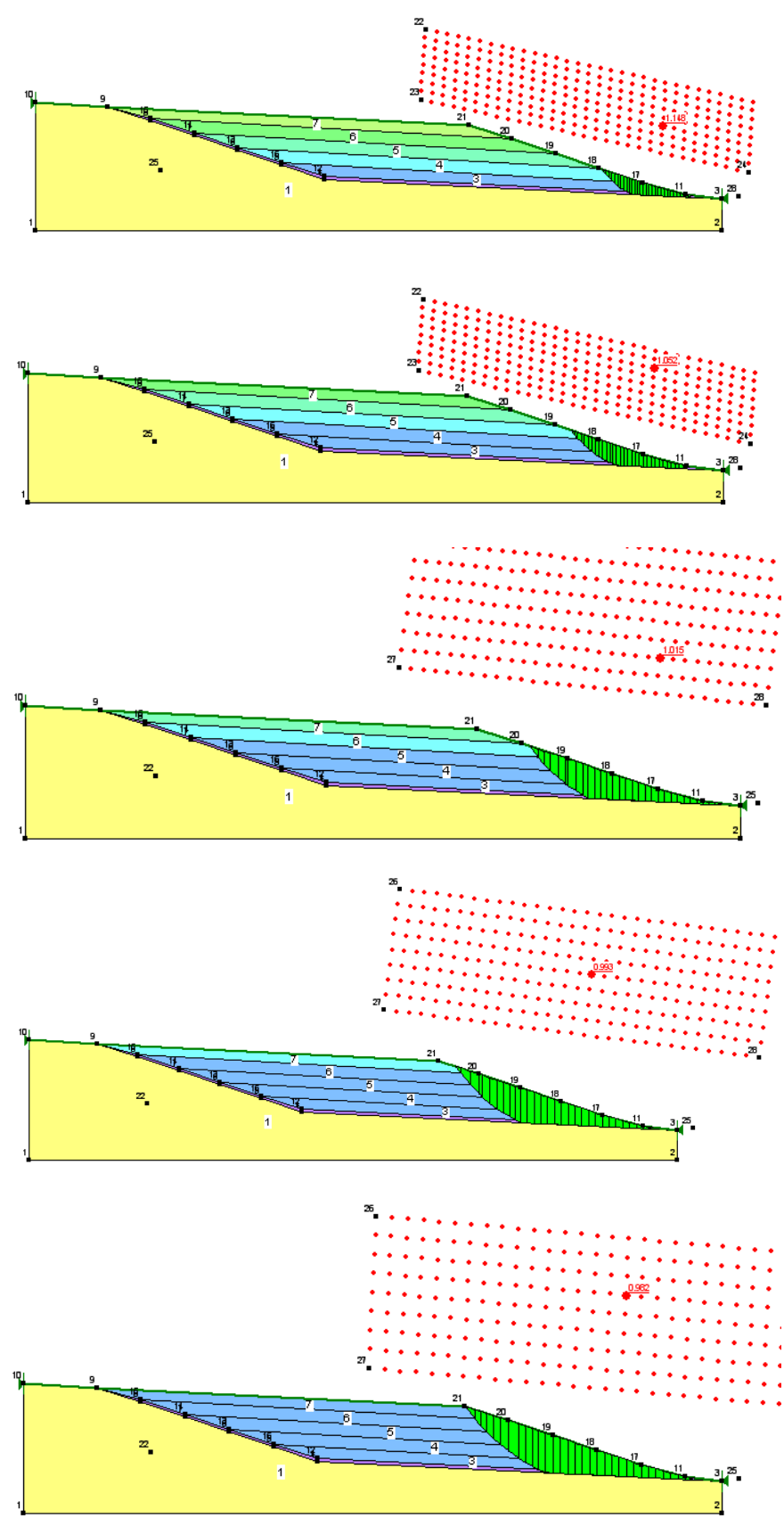

Fig. 4. Critical failure surfaces and factors of safety at different stages of decomposition

conclude that stability calculations are very important in deposition procedure design; otherwise unrealizable construction plans may be created.

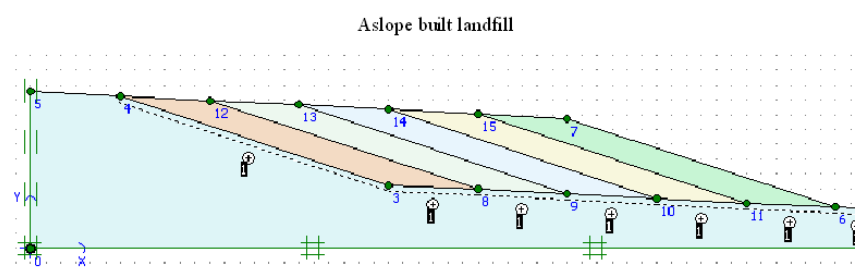

Fig. 5. Aslope built landfill

In case of staggered built landfill, wastes are deposited in dif- 
ferent conditions like a stagger. Fig. 6 shows the geometry of the examined landfill.

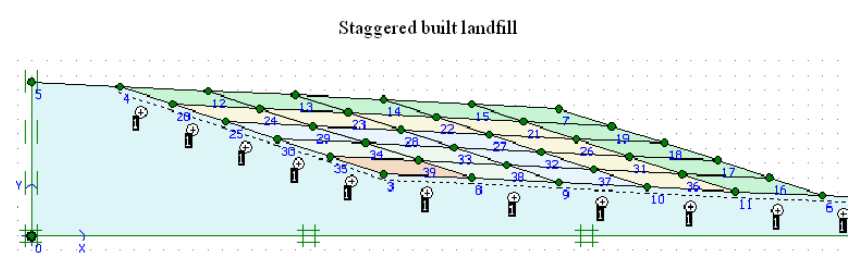

Fig. 6. Staggered built landfill

Similarly to other geometries we performed calculations with the help of PLAXIS and GEOSLOPE and we determined the magnitude of factors of safety and the locations of failure surfaces. Results in case of parallel and staggered built landfills are shown in Table 5 and Fig. 7

We can conclude that landfilling techniques have major effect on factor of safety. In case of staggered built landfills both simulations resulted in higher factor of safety values than those of parallel built landfills.

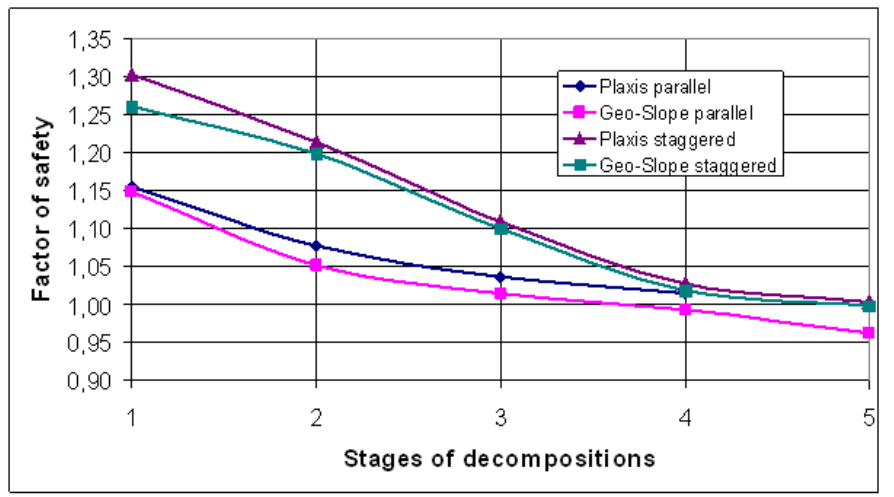

Fig. 7. Factors of safety at different stages of decompositions in case of parallel and staggered built landfills using PLAXIS and GEOSLOPE simulations

In stage 5 when the entire waste body reached the last degradation stage and the examined waste structure is uniform, we also got a bit larger factor of safety in case of staggered landfill. It can be explained by the fact, that part of the settlement process of the first waste layer had already been taken place when the second waste layer was laid down, which means different initial conditions for the next calculation step in each type of geometry. Accordingly, we propose the application of the staggered deposition technique in order to build landfills with higher stability. We have observed that the aslope built landfilling technique, commonly used in developing countries, has many disadvantages and higher chances of critical failures. Application of this technique should be ceased as soon as possible based on the number of fatal catastrophes all over the world.

\section{Conclusions}

We examined bioreactor landfills stability with respect to degradation. Our model divided the waste body into five layers according to the degree of decomposition. Three different geometries were simulated. We used PLAXIS and GEOSLOPE program in our simulations then we compared their results. We have found that the geometry of landfilling has a major impact on slope stability. In case of aslope landfilling technique the slope became unstable already in the first phase, while stability of the totally filled up landfill was sufficient. We can conclude that stability calculations are very important in deposition procedure design, otherwise unexpected failures may happen.

Factor of safety decreased with the advancement of degradation, in all simulated geometries. Accordingly, we propose that the stability of bioreactors should be determined with shear strength parameters defined as a function of degradation (and time). Commonly applied fresh waste- or average-based parameters may generate unjustifiably high safety factors, which may result in unexpected stability problems. Constant monitoring of landfills is recommended in order to determine the phases of degradation, which may also help in optimizing biogas utilization.

Based on our comparisons we conclude that the safety factor is higher in the staggered geometry in all stages of decomposition. In the final stage when the whole waste body reached the last degradation phase and examined waste structure is uniform, the staggered landfill still showed a slightly higher safety factor. It shows that the geometry of landfilling technique plays a major role in its stability. We recommend the usage of staggered geometry for landfills.

We have performed our simulations both with PLAXIS and GEOSLOPE. The results of the two sets of simulations are very close despite their different approaches. It shows the reliability of the generated geotechnical model.

We have created a geotechnical model to determine the time (degree of degradation) dependent stability of bioreactor landfills. The model is suited for:

- To examine and optimize deposition strategy

- To predict the time dependent changes of

- Stability

- Potential instable waste body

- Surface settlement.

- To create a monitoring strategy and related alarm levels.

\section{References}

1 Czap Zoltán, Geotechnikai szoftverek összehasonlítása, 2002. Ráckeve.

2 Dixon N, Jones D R V, Whittle R W, First Mechanical properties of household waste: In-situ assessment using pressurementer, 7th International Waste Management and Landfill Symposium (Sardinia, 1999), pp. 453-460.

3 Florida Bioreactor Landfill Demonstration Project-Executive Summary, Center for Solid and Hazardous Waste Management, 2008. http://www.bioreactor.org/publications.htm.

4 GeoStudio Tutorials, 2004.

5 Hossain M S, Haque M A, The Effect of Daily Cover Soils on Shear Strength Parameters of Municipal Solid Waste with Degradation in Bioreactor Landfills, Waste Management Journal 29 (2009), no. 5, 1568-1576. 
Tab. 5. Factors of safety at different stages of decompositions in case of parallel and staggered built landfills using PLAXIS and GEOSLOPE simulations

\begin{tabular}{ccccccccccc}
\hline & \multicolumn{2}{c}{ Stage 1 } & \multicolumn{2}{c}{ Stage 2 } & \multicolumn{2}{c}{ Stage 3 } & \multicolumn{2}{c}{ Stage 4 } & \multicolumn{2}{c}{ Stage 5 } \\
& Parallel & Staggered & Parallel & Staggered & Parallel & Staggered & Parallel & Staggered & Parallel & Staggered \\
\hline PLAXIS & 1,155 & 1,303 & 1,077 & 1,213 & 1,037 & 1,109 & 1,015 & 1,028 & - & 1,003 \\
\hline GEO-SLOPE & 1,148 & 1,261 & 1,052 & 1,198 & 1,015 & 1,100 & 0,993 & 1,018 & 0,962 & 0,998 \\
\hline
\end{tabular}

6 Imre E, Farkas J, Kovács M, Czap Z, Trang Q P, "Sovány gázok" sikere, Mélyépítő Tükörkép Magazin 6 (2007), 4-7.

7 Bioreactor Landfill for Sustainable Solid Waste Landfill Management, Kasetsart University, Thailand, 2004.

8 Hughes K L, Christy A D, Heimlich J E, Bioreactor Landfills, Ohio State University Fact Sheet Extension. CDFS-139-05.

9 Koelsch F, Fricke K, Mahler C, Damanhuri E, Stability of landfills- The Bandung dumpsite disaster, 10th International Waste management and Landfill Symposium (Sardinia, Italy, 2005). On CD-Rom.

10 Reddy K R, Bogner J E, Bioreactor Landfill Engineering for Accelerated Stabilization of Municipal Solid Waste, International e-Conference on Modern Trends in Foundation Engineering: Geotechnical Challenges and Solutions (Indian Institute of Technology, Madras, 2003), pp. 22.

11 Pohland F G, Harper S R, Critical Review and Summary of Leachate and Gas Production From Landfils, Cincinnati, OH, U.S.A.: U.S. Environmental Protection Agency, 1986. EPA/600/2-86/073.

12 Szabó I, Hulladéklerakók lezárása és rekultivációja II., 2009. Oktatási segédlet.

13 Varga G, Applications of Different Soil Models for Stability Experiments, The 2nd International Young Geotechnical Engineers' Conference (Mamaia, 2003), pp. 101-102.

14 Varga G, Czap Z, Hulladéklerakók végeselemes vizsgálatai, Gazdasági Tükörkép Magazin X. (2010), 52-53.

15 _ Soil models: Safety Factors and Settlements, Periodica Polytechnika. Ser.Civ.Eng. 48 (2004), no. 1-2., 53-64.

16 Westakle K, Sustainable landfill - possibility or pipe dream, Waste management and research 15 (1997), 453-461.

17 Zekkos D P, Bray J D, Kavazanjian E, Matasovic N, Rathje E M, Riemer M F, Stokoe K H, Unit weight of municipal solid waste, Journal of Geotechnical and Geoenvironmental Engineering 132 (2006), no. 10, 12501261. 